\title{
MICROCYSTINS UPTAKE BY THE YELLOW CLAM MESODESMA MACTROIDES (BIVALVIA, MACTROIDEA)
}

\author{
JANAINA DE CASTRO LEÃO; SHEILA BUENO GIORDANO; JOÃO SARKIS YUNES \\ Universidade Federal do Rio Grande - Instituto de Oceanografia - Unidade de Pesquisa em Cianobactérias - \\ Av. Itália Km 8, Campus Carreiros, Caixa Postal: 474, CEP: 96201-900 -Rio Grande, RS - Brazil
}

1'iclea077@yahoo.com.br

\begin{abstract}
Microcystins (MCYST), common cyanobacterial hepatotoxins, have been observed in the Patos Lagoon and the estuary over the last three decades. Anthropogenic pollution associated to the environmental features has promoted the frequent occurrence of cyanobacterial blooms in this environment. The present work aimed to evaluate the MCYST uptake by the filter-feeding mollusk Mesodesma mactroides Deshayes, 1854, which occurs in the nearby coasts of the Patos Lagoon estuary, Brazil. Bioassays were carried out using the toxic strain Microcystis aeruginosa RST9501, isolated from the Patos Lagoon estuary. Clams were exposed to live cells of this toxic cyanobacterium for 12 days, taking up MCYST to a maximum of $5.27 \pm 0.23 \mu \mathrm{g}$ MCYST.g ${ }^{-1}$ (dry hepatopancreas weight). Since several blooms reaching the Patos Lagoon estuary and the nearby areas are observed, these results indicate that the toxins from $M$. aeruginosa blooms can be accumulated by this filter-feeding animal, making it a potential vector to the local trophic web.
\end{abstract}

KEY WORDS: Patos Lagoon, Microcystis, microcystin, Mesodesma, bioaccumulation.

\section{RESUMO}

Retenção de microcistinas pelo marisco Mesodesma mactroides (Bivalvia, Mactroidea)

As microcistinas (MCYST), hepatotoxinas produzidas por cianobactérias, tem sido encontradas na Lagoa dos Patos e seu estuário ao longo dos últimos trinta anos. A poluição antropogênica associada com as características ambientais locais tem favorecido a ocorrência de florações de cianobactérias nesse ambiente. O presente trabalho teve como objetivo avaliar a assimilação de MCYST pelo molusco filtrador Mesodesma mactroides Deshayes,1854, que ocorre na costa adjacente ao estuário da Lagoa dos Patos, Brasil. Experimentos em laboratório foram realizados utilizando uma cepa tóxica da espécie Microcystis aeruginosa RST9501, isolada do estuário da lagoa dos Patos. Os mariscos foram expostos a células vivas da

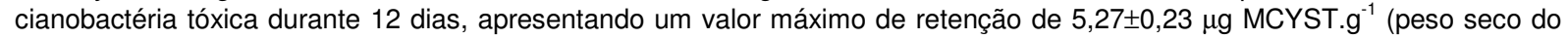
hepatopâncreas). Uma vez que diversas florações contendo $M$. aeruginosa atingindo o estuário da Lagoa dos Patos e áreas costeiras são observadas, os resultados indicam que essas toxinas, comuns nessas florações, podem ser acumuladas por esse animal filtrador, tornando-o um potencial vetor para a teia trófica local.

PALAVRAS CHAVE: Lagoa dos Patos, Microcystis, microcistina, Mesodesma, bioacumulação.

\section{INTRODUCTION}

Microcystins (MCYST), common cyanobacterial hepatotoxins, inhibit protein phosphatases enzymes PP1 and PP2A and induce oxidative stress in different organisms as macrophytes, polychaetes, crab and fish, causing cell damage (Pflugmacher, 2004; Dewes et al., 2006, Pietro et al., 2006, Leão et al., 2008).

Anthropogenic pollution has promoted cyanobacterial toxic blooms in water bodies worldwide. Several blooms containing toxic Microcystis aeruginosa cells, able to produce MCYST, have occurred in the Patos Lagoon (Southern Brazil) over the last three decades with effects on the aquatic life. Alterations of biochemical and physiological parameters in several aquatic organisms have been observed (Yunes et al., 1998; Pinho et al., 2005; Rosa et al., 2005; Dewes et al., 2006, Leão et al., 2008).

The Patos Lagoon $\left(30^{\circ} 20^{\prime} \mathrm{S}\right.$ to $\left.32^{\circ} 10^{\prime} \mathrm{S}\right)$ is the second largest inland water body in Brazil and the largest lagoonal complex in South America. Along its margins more than three million inhabitants live in several cities and villages, using its waters as a domestic supply and for leisure, fisheries, agriculture, navigation and as a final recipient of domestic and industrial sewage (Yunes et al., 1998).

$M$. aeruginosa occurs in the Patos Lagoon estuary during all over the year, especially in summer and spring, when blooms are common events. Frequently, cyanobacterial blooms from the Patos Lagoon reach the estuary and the nearby seacoast (Matthiensen et al., 1999).

Shellfish can filter large volumes of waters containing toxic substances leading to uptake and accumulation of toxins. Previous studies have observed that cyanotoxins do not cause toxic effects in filter-feeding mollusks, which make them a consumption risk (Vasconcelos, 1995; Christoffersen, 1996; Williams et al., 1997; Amorim e Vasconcelos, 1999).

Mesodesma mactroides Deshayes, 1854 is endemic in the Atlantic coast of South America, occuring from llha Grande $\left(23^{\circ} \mathrm{S}\right.$, Rio de Janeiro 
state), Brazil, to the Rio Negro mouth $\left(41^{\circ} \mathrm{S}\right.$, province of Buenos Aires), Argentina. This clam can reach a length of $80 \mathrm{~mm}$ diameter and it is frequently found buried in the beaches nearby to the Patos Lagoon estuary (Mar Grosso and Cassino beaches). It is used as food resource and as bait for fisheries (Rios, 1994).

The present work aimed to evaluate the MCYST uptake capacity by the yellow clam $M$. mactroides and detect its potential as vector and/or indicator of cyanotoxin bioaccumulation in the food web.

\section{MATERIAL AND METHODS \\ Sampling of clams}

Specimens of $M$. mactroides $(n=150)$ were collected in the Mar Grosso beach (Brazil) (Figure 1) using a shovel and immediately transferred to the laboratory. The organisms were adapted to the laboratory conditions for $92 \mathrm{~h}$ in a tray containing 10 $\mathrm{Kg}$ of autoclaved beach sand and $20 \mathrm{~L}$ of filtered (300 $\mu \mathrm{m}$ mesh) marine water at laboratory temperature and photoperiod. An air pump was kept during the acclimation period. The average diameter of the organisms was $20.85 \pm 7.43 \mathrm{~mm}$ (Figure 2).

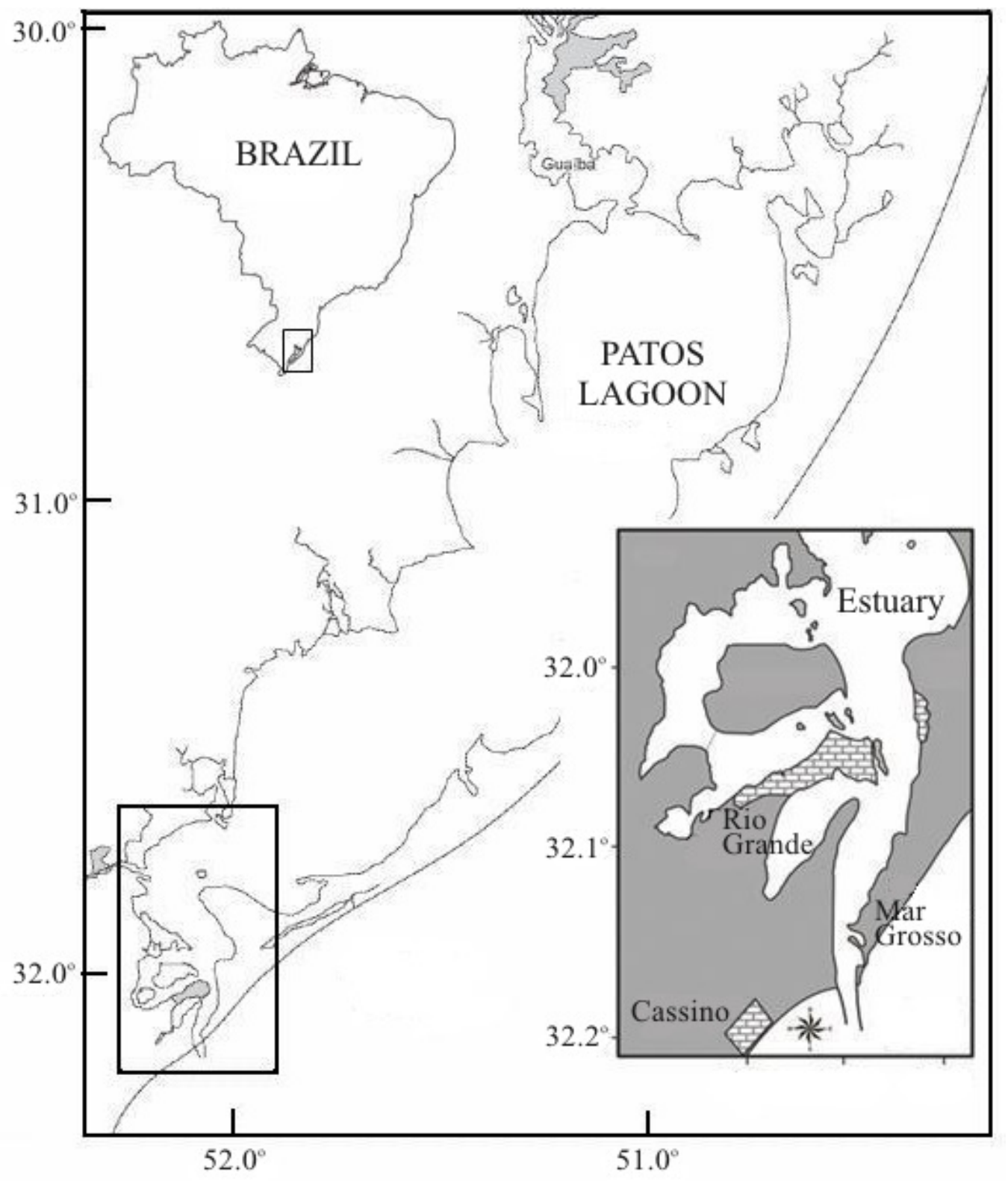

Figure 1: Location of the sampling area in Brazil. 


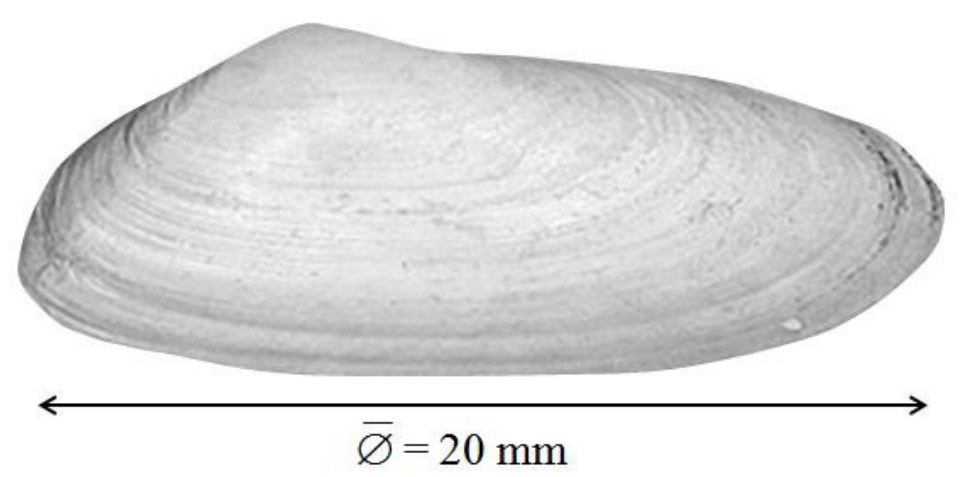

Figure 2: Mesodesma mactroides

\section{Accumulation experiment}

Cells of a toxic $M$. aeruginosa strain (RST 9501) isolated from the Patos Lagoon (Matthiensen et al., 2000) were cultured in modified BG-11 medium (Rippka et al, 1979) and employed as source of MCYST. According to Matthiensen et al. (2000), [DLeu ${ }^{1}$ JMCYST-LR is the major MCYST variant produced by this Microcystis strain. This variant presented an $\mathrm{LD}_{50}$ value of $71 \mu \mathrm{g} \cdot \mathrm{kg}^{-1}$, while MCYST-LR and MCYST-RR presents $L_{50}$ values of 50 and $320 \mu \mathrm{g} \mathrm{kg}^{-1}$, respectively, in mouse bioassay (Chen et al, 2006).

A bioassay using two constant densities (treatments) of live Microcystis cells was carried out on a daily water exchange basis. During the experiment, an air pump was kept in each tank in order to maintain the water oxygenation. For the MCYST contents analysis, the organisms were removed from their shells and the hepatopancreas were separated, weighed (wet weight) and frozen (for unsettled time).

The experiment was carried out in three separated tanks with $2 \mathrm{~kg}$ of autoclaved beach sand and $3 \mathrm{~L}$ filtered (300 $\mu \mathrm{m}$ mesh) marine water at laboratory temperature and photoperiod. Thirty organisms were distributed in each tank. Every day Microcystis cells were added after water renovation. Three groups were tested: The first group received a cellular density of $1 \times 10^{6}$ Microcystis cells. $\mathrm{L}^{-1}$ (Treatment 1), reaching $0,4 \pm 0,04 \mu \mathrm{gMCYST} . \mathrm{L}^{-1}$; the second group received a density of $10 \times 10^{6}$ Microcystis cells. $\mathrm{L}^{-1}$ (Treatment 2), reaching $0,7 \pm 0,08$ $\mu$ gMCYST. $L^{-1}$; the third group was the control (absence of Microcystis cells). At each three days, three random organisms and $1.5 \mathrm{ml}$ of water sample were taken from each tank. The experiment was carried out for 12 days.

\section{Microcystins extraction and analysis}

MCYST extraction followed an adaptation of the method described by Magalhães et al. (2001). Each hepatopancreas was freeze-dried, ground and weighed (dry weight). Fifteen $\mathrm{mL}$ of methanol was added to each hepatopancreas powder, which were kept for two hours in an orbital shaker at $80 \mathrm{rpm}$, and 15 hours at $4^{\circ} \mathrm{C}$. Later, samples were centrifuged (Hermle, Labnet 323) at 5,000 $\mathrm{x} g$ during 20 minutes. The supernatants were removed and added to separation funnels and the pellets were re-extracted in $15 \mathrm{~mL}$ of methanol and again centrifuged at $5,000 \times \mathrm{g}$ during 20 minutes. The new supernatants were added to the previous (in the funnel) and $30 \mathrm{~mL}$ of hexan was added. After 5 minutes, the methanolic fractions were evaporated in a rotatory evaporator at $55-60{ }^{\circ} \mathrm{C}$ and re-suspended in 1 $\mathrm{ml}$ of ultrapure water (MilliQ). The hexanolic fractions were discharged. The aqueous fractions were centrifuged at $12,000 \times \mathrm{g}$ (Eppendorf centrifuge 5415 C) during 10 minutes and the supernatants were used for the toxins analysis using an enzyme-linked imunossorbent assay (ELISA) kit with a detection limit of 0.1 to $5.0 \mathrm{ppb}$ (ABRAXIS, USA).

The water samples were sonicated during 3 minutes for cells rupture, centrifuged at $12.000 \times \mathrm{g}$ (Eppendorf centrifuge $5415 \mathrm{C}$ ) during 10 minutes and the supernatants were used for the MCYST analysis using the ELISA kit described above. 


\section{Microcystins contents calculation}

MCYST values in the clam's hepathopancreas were converted to $\mu \mathrm{g} \cdot \mathrm{g}^{-1}$ as following:

$$
[\mathrm{MC}] \mu \mathrm{g} \cdot \mathrm{g}^{-1}=\frac{\left(\frac{[\mathrm{MC}] \mu \mathrm{g} \cdot \mathrm{L}^{-1}}{\mathrm{DHW}(\mathrm{g})}\right)}{1000}
$$

Where:

[MCYST] $\mu \mathrm{g} \cdot \mathrm{g}^{-1}=$ MCYST concentrations in $1 \mathrm{~g}$ dry hepatopancreas weight;

[MCYST] $\mu . L^{-1}=$ MCYST concentrations in 1 liter of the hepatopancreas extract;

DHW $(\mathrm{g})=$ dry hepatopancreas weight.

Data were subjected to the factorial ANOVA $(\alpha=0.05)$ followed by the Tukey HSD test (post-hoc).

\section{RESULTS}

M. mactroides shows tolerance to the laboratory conditions, presenting low mortality rate $(13 \%)$, which it (mortality) was not related to the toxin exposure.

MCYST concentrations in the water samples have been constant along the experiment in both treatments 1 and $2(0.4 \pm 0.04$ and $0.7 \pm 0.08 \mu \mathrm{g}$ MCYST. $L^{-1}$, respectively). A small amount of MCYST in the water of the control tank $(0.1 \pm 0.03) \mu \mathrm{g}$ MCYST. $L^{-1}$, was observed and was constant during the experiment.

Figure 3 shows an increase of the MCYST contents in the hepatopancreas of the organisms exposed to both treatments 1 and 2, during 12 days exposure time.

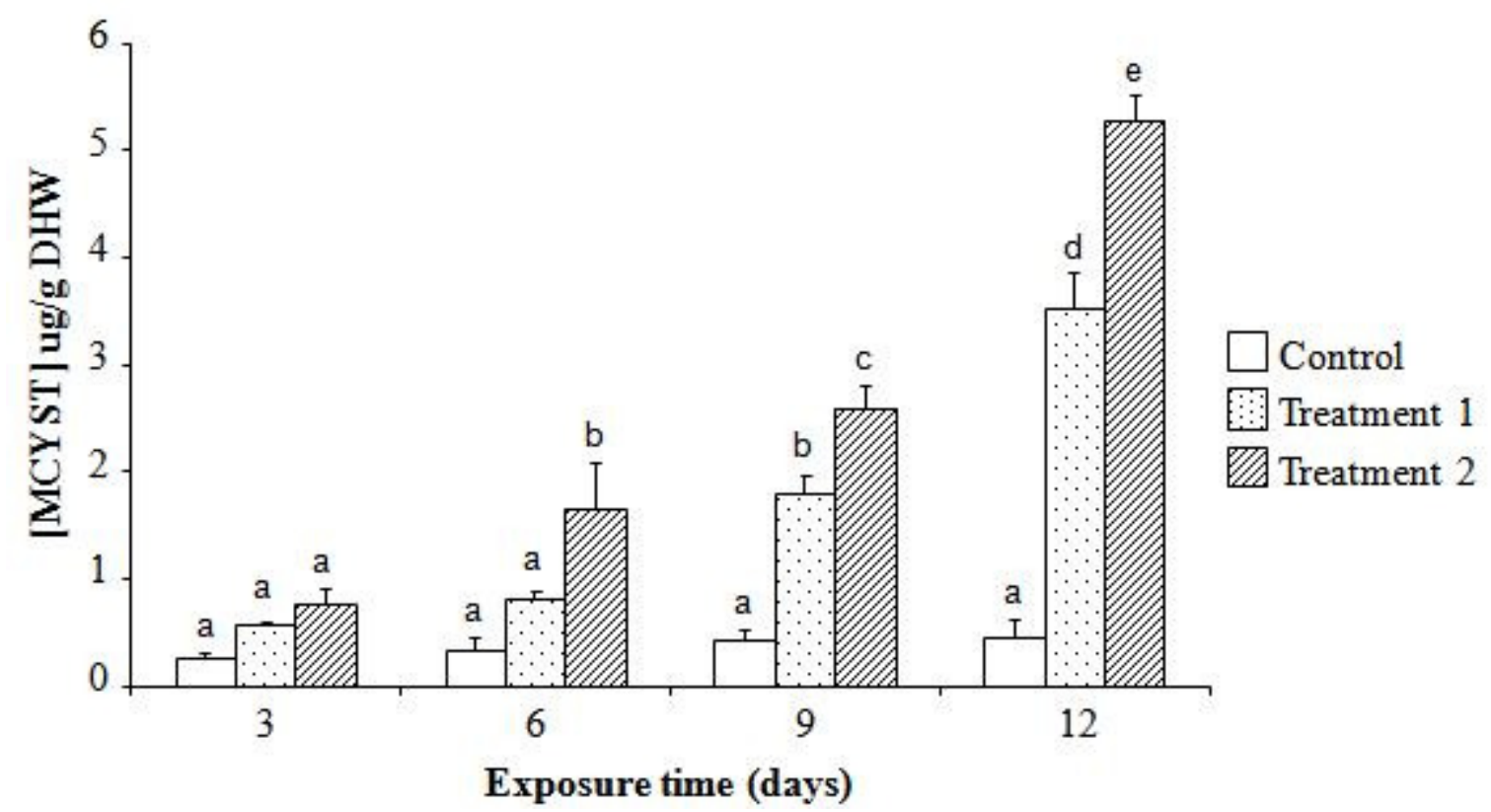

Figure 3: Mycrocistin (MC) contents $(\mu \mathrm{g})$ in $1 \mathrm{~g}$ dry hepatopancreas weight (DHW) of the control organisms and the organisms exposed to $1 \times 10^{6}$ and $10 \times 10^{6}$ live Microcystis cells. $\mathrm{L}^{-1}$ (treatment 1 and 2, respectively) during 12 days exposure time. Data are expressed as mean + standard error. Similar letters indicates absence of statistical significance $(p \geq 0.05)$

The occurrence of small amounts of MCYST in both, water and organisms of the control tank, indicates a possible contamination source or a false positive presented by the enzymatic assay used in the MCYST analysis. However, MCYST contents in the control organisms did not show significant differences during the experiment

In the control organisms, factorial ANOVA followed by the Tukey HSD test have shown that there were no significant differences among the MCYST concentration averages, during the experiment. Only at the beginning (until 3 days exposure time) the MCYST values in the control organisms and in the organisms exposed to treatments 1 and 2 were statistically similar. After 3 days exposure time, a gradual increase of the MCYST contents was observed in the organisms exposed to treatment 2. The results showed no difference of the MCYST 
contents in the organisms exposed to treatment 1 until 6 days exposure time, after, a gradual increase was observed. Differences between MCYST concentrations average were considered significant when $p \leq 0.05$ and the $95 \%$ confidence limits did not overlap.

\section{DISCUSSION}

The mortality rate of $M$. mactroides in the laboratory was low (13\%), and it was not associated to the presence of MCYST since the rate was measured using dead organisms of all treatments and there was not a correlation among them.

The experiment was carried out for 12 days, which was enough to show MCYST uptake and accumulation by the clam. Williams et al. (1997), Amorim \& Vasconcelos (1999) and Yokoyama \& Park (2002) suggested that the shellfish health is not affected by MCYST, becoming a vector of cyanotoxins to the following trophic level.

MCYST contents in the control organisms were constant during the accumulation process. MCYST contents in the control tank (which received the same treatment except for the Microcystis cells addition) indicated a possible contamination source. This may be due to the water used in the daily exchange or due the aeration spray generated by the air pumps, since the tanks were kept side by side. A possible false positive generated during the MCYST analysis cannot be rejected. The ELISA kit have a high sensitivity level and such commercial kits are susceptible to methanol, salinity, $\mathrm{pH}$, plasticware and cyanobacterial extract interferences (Metcalf et al. 2000).

A few studies reported $M$. mactroides biology and ecology. Studies using $M$. mactroides are scarce since this species only occurs in the Atlantic coasts of South America. According to Cárdenas et al. (1994), $M$. donacium is an efficient indicator of heavy metals levels.

Some authors showed that MCYST is accumulated in tissue of aquatic organisms. Pires et al. (2004) showed the assimilation and depuration dynamic of MCYST in the filter-feeding mollusk Dreissena polymorpha. Xie et al. (2007) observed MCYST accumulation in various organs of the freshwater snail Sinotaia histrica. In a review, lbelings \& Chorus (2007) have shown accumulation of cyanobacterial toxins in "seafood" collected from freshwater and coastal areas, which include fish, snail, bivalve, crab, shrimp, etc. Lance et al. (2008) observed the increase of MCYST contents in the gastropod organism Potamopyrgus antipodarum exposed to oral ingestion of toxic Planktothrix agardii. Deblois et al. (2008) have shown MCYST accumulation in different tissues (liver and muscle) of tilapia fish.

In this work, it has been observed an accumulation of MCYST in the clams exposed to both treatments (1 and 2) during the test. The organisms exposed to the treatment 2 have taken up more MCYST than the organisms exposed to the treatment 1. These results indicate a relationship between the amount of MCYST available in the environmental water and the amount of MCYST which has been taken up by the shellfish.

The capacity to accumulate toxic substances (toxins, metals, etc.) by filter-feeding organisms, especially bivalve mollusks, is well known. Filterfeeding organisms retain suspension material taking up toxic substances, leading to accumulation. Some syndromes known as PSP (Paralytic Shellfish Poisoning), NSP (Neurotoxic Shellfish Poisoning), ASP (Amnesic Shellfish Poisoning) and DSP (Diarrheic Shellfish Poisoning) have been reported in populations that use shellfish as food source (Backer et al., 2005). Thus, toxic substances become available in the trophic web making filter-feeding organisms a consumption risk (Christoffersen, 1996).

Blooms of Microcystis reaching the estuarine areas have become a feature in the Patos Lagoon. Total MCYST concentrations in the estuarine surface water have varied in a very wide range of values (from trace to several milligrams per liter), being strongly influenced by the occurrence of cyanobacterial biomass.

The yellow clam is consumed by human and several species of birds and fishes that are also part of the human food web. Vasconcelos (1995) reported that $96 \%$ of the total MCYST in mussels are in the digestive tract and suggest that a consumption of $625 \mathrm{~g}$ total wet weight of the mussel Mytilus galloprovincialis, used in a MCYST accumulation bioassay, represents an ingestion of $250 \mu \mathrm{g}$ MCYST, considering that the organisms took up MCYST to a maximum of $10.5 \mu \mathrm{g}$ MCYST.g ${ }^{-1}$ (dry weight) (highest value). The highest value observed in this work was $5.27 \pm 0.23 \mu \mathrm{g}$ MCYST.g ${ }^{-1}$ (dry hepatopancreas weight), which is equivalent to $1.0 \mu \mathrm{g} \cdot \mathrm{g}^{-1}$ 
(wet hepatopancreas weight) considering that the dry hepatopancreas weight average was $0.01 \pm 0.05 \mathrm{~g}$ and the wet hepatopancreas weight average was $0.06 \pm 0.03$ g. Thus, according to this work, considering that the total wet weight average of the clams was $0.30 \pm 0.13 \mathrm{~g}$, a consumption of $625 \mathrm{~g}$ total wet weight represents an ingestion of $112 \mu \mathrm{g}$ MCYST. Bartram et al. (1999) recommend a daily intake limit of $0.045 \mu \mathrm{g}$ MCYST per $\mathrm{Kg}$ of a person. Thus, for a $70 \mathrm{Kg}$ person the daily intake limit is $3.15 \mu \mathrm{g}$ MCYST, and a consumption of $17.5 \mathrm{~g}$ total wet weight of this clam is enough to reach such limit.

\section{ACKNOWLEDGEMENTS}

We thank to the Brazilian agency CNPq for its support during the tenure of the MSc student J.C. Leão and the graduating student S.B. Giordano and for research grants. J.S. Yunes is research fellow of the $\mathrm{CNPq}$.

\section{REFERENCES}

AMORIM, A \& V VASCONCELOS. 1999. Dynamics of Microcystins in the Mussel Mytilus galloprovincialis. Toxicon, 37: 1041-1052.

BACKER, LC, H SCHURZ-ROGERS, LE FLEMING, B KIRKPATRICK \& J BENSON. 2005. Chapter 7: Marine Phycotoxins in Seafood. In: Dabrowski, WM \& Sikorski, ZE (Eds). Toxins in food. CRC press LLC, Florida, USA: 155-190.

BARTRAM, J, WW CARMICHAEL, G JONES \& OM SKULBERG. 1999. Introduction. In: Chorus, I \& Bartram, J (Eds). Toxic Cyanobacteria in Water: A Guide to their Public Health Consequences, Monitoring and Management. WHO, E. \& FN Spon, London: 1-14.

CÁRDENAS, T, RG TRUCCO \& J INDA. 1994. Cd, Cu, and Fe levels in Mesodesma donacium of the El Faro, Peñuelas and Morrillos Beaches, IV Region, Chile. The Sci. Tot. Environ., 142: 207-211

CHRISTOFFERSEN, K. 1996. Ecological Implications of Cyanobacterial Toxins in Aquatic Food Webs., Phycologia 35: 42-50.

DEBLOIS, CP, R ARANDA-RODRIGUEZ, A GIANI \& DF BIRD. 2008. Microcystin Accumulation in Liver and Muscle of Tilapia in Two Large Brazilian Hydroelectric Reservoirs. Toxicon, 51: 435-448.

DEWES, LJ, JZ SANDRINI, JM MONSERRAT \& JS YUNES. 2006. Biochemical and Physiological Responses After Exposure to Microcystins in the Crab Chasmagnathus granulatus (Decapoda, Brachyura). Ecotoxicol. Environ. Saf., 65: 201-208

IBELINGS, BW \& I CHORUS. 2007. Accumulation of Cyanobacterial Toxins in Freshwater "Seafood" and Its Consequences for Public Health: A review. Environ. Poll., 150: 177-192.

LANCE, E, E BUGAJNY, N BORMANS \& C GÉRARD. 2008. Consumption of Toxic Cyanobacteria by Potamopyrgus Antipodarum (Gastropoda, Prosobranchia) and Consequences on Life Traits and Microcystin Accumulation. Harmful algae, 7: 464-472.

LEÃO, JC, LA GERACITANO, JM MONSERRAT, LL AMADO \& JS
These results show that not only the yellow clam M. mactroides is able to accumulate MCYST but the amount of MCYST taken up by the clam is proportional to the MCYST contents available in the environmental water. As a matter of this fact, we conclude that $M$. mactroides is a vector of this toxin through the food web. It denotes a high contamination risk by direct consumption of the clam, which is frequently exposed to toxic cyanobacterial blooms that reach the beaches nearby to the Patos Lagoon estuary. Moreover, this organism can be regarded as an important bioindicator of toxic substances in management studies of polluted waters.

YUNES. 2008. Microcystin-Induced Oxidative Stress in Laeonereis acuta (Polychaeta, Nereididae). Mar. Environ., 66: 92-94.

MAGALHÃES, VF, RM SOARES \& SMFO AZEVEDO. 2001. Microcistin Contamination in Fish from the Jacarepaguá Lagoon (Rio de Janeiro, Brazil): Ecological implication and Human Health Risk. Toxicon, 39: 1077-1085.

MATTHIENSEN, A, JS YUNES \& GA CODD. 1999. Ocorrência, Distribuição e Toxicidade de Cianobactérias no Estuário da Lagoa dos Patos, R. S. Rev. Brasil. Biol., 59(3): 361-376.

MATTHIENSEN, A, KA BEATTIE, JS YUNES, K KAYA \& GA CODD. 2000. [D-Leu ${ }^{1}$ Microcystin-LR, from the cyanobacterium Microcystis RST 9501 and from a Microcystis bloom in the Patos Lagoon estuary, Brazil. Phytochemistry, 55:383-387.

METCALF, JS, P HYENSTRAND, KA BEATTIE, GA CODD. 2000. Effect of physicochemical variable and cyanobacterial extract on the immunoassay of microcystin-LR by two ELISA kit. $J$. Appl. Microbiol., 89: 532-538

PFLUGMACHER, S. 2004. Promotion of oxidative stress in the aquatic macrophyte Ceratophyllum demersum during biotransformation of the cyanobacterial toxin microcystin-LR. Aquat. Toxicol., 70: 169-178

PIETRO, AI, A JOS, S PICHARDO, I MORENO, AM CAMEÁN. 2006. Differential oxidative stress responses to microcystins LR and $\mathrm{RR}$ in intraperitoneally exposed tilapia fish (Oreochromis sp.). Aquat. Toxicol., 77: 314-321

PINHO, GLL, CM ROSA, FE MACIEL, A BIANCHINI, JS YUNES, LA PROENÇA \& JM MONSERRAT. 2005. Antioxidant Responses and Oxidative Stress After Microcystin Exposure in the Hepatopancreas of an Estuarine Crab Species. Ecotoxicol. Environ. Saf., 61: 353-360

PIRES, LMD, KM KARLSSON, JAO MERILUOTO, E KARDINAAL, PM VISSER, K SIEWERTSEN, EV DONK \& BW IBELINGS. 2004. Assimilation and Depuration of Microcystin-LR by the Zebra Mussel, Dreissena polymorpha. Aquat. Toxicol., 69: 385386.

RIOS, E. 1994. Seashells of Brazil. 2ª ed. Fundação Universidade Federal do Rio Grande Editor. Rio Grande, RS, 368p.

RIPPKA, R, J DERUELLES, JB WATERBURY, M HERDMAN \& RY STANIER, R.Y. 1979. Generic assigments, strain histories and properties of pure cultures of cyanobacteria. J. Gen. Appl. 
Microbiol., 111: 1-61.

ROSA, CE, MS SOUZA, JS YUNES, LAO PROENÇA, LEM NERY \& JM MONSERRAT. 2005. Cyanobacterial Blooms in Estuarine Ecosystems: Characteristics and Effects on Laeonereis acuta (Polychaeta, Nereididae). Mar. Polut. Bull., 50: 956-964

VASCONCELOS, VM. 1995. Uptake and Depuration of the Hepatotoxin Microcistin-LR in Mytilus galloprovincialis. Aquat. Toxicol., 32: 227-237.

WILLIAMS, DE, SC DAWE, ML KENT, RJ ANDERSEN, M CRAIG \& CFB HOLMES. 1997. Bioaccumulation and Clearence of Microcystins from Salt Water Mussels, Mytilus edulis, and in Vivo Evidence for Covalently Bound Microcystins in Mussel Tissue. Toxicon, 35 (11):1617-1625.

XIE, L, A YOKOYAMA, K NAKAMURA \& H PARK. 2007.
Accumulation of Microcystins in Various Organs of the Freshwater Snail Sinotaia Histrica and Three Fishes in a Temperate Lake, the Eutrophic Lake Suwa, Japan. Toxicon, 49: 646-652.

YOKOYAMA, A \& H-D PARK. 2002. Mechanism and Prediction for Contamination of Freshwater Bivalves (Unonidae) with the Cyanobacterial Toxin Microcystin in Hypereutrophic Lake Suwa, Japan. Environ. Toxicol., 17: 424-433.

YUNES, JS, A MATTHIENSEN, M PARISE, PS SALOMON, SL RAGGETT, KA BEATTIE \& GA CODD. 1998. Microcystis aeruginosa Growth Stages and the Occurrence of MCs in Patos Lagoon, Southern Brazil. Hamful Algae. Xunta de Galicia and Intergovernmental Oceanografic Comisión of UNESCO. Pp. 18-21.

Recebido: 06/02/2009

Aceito: 05/11/2009 
